\title{
AYAM LEHER GUNDUL: SEJARAH, KARAKTERISTIK, DAN KONSERVASI
}

\author{
KOSTAMAN, T. \\ Balai Penelitian Ternak, Jl. Veteran III, Ciawi-Bogor 16720 \\ e-mail: tatankostaman@gmail.com
}

\begin{abstract}
ABSTRAK
Ayam leher gundul adalah ayam asli/lokal Indonesia yang belum banyak diketahui informasinya dalam hal sejarah, potensi, dan karakteristik; sehingga belum dimanfaatkan secara optimal. Ciri yang paling menonjol dari ayam leher gundul adalah tidak mempunyai bulu dibagian lehernya. Untuk mempertahankannya, metode konservasi yang telah dilakukan oleh Balai Penelitian Ternak (Balitnak) adalah dengan memelihara ternak hidup, akan tetapi dengan keterbatasan sarana dan prasarana tidak dapat dilanjutkan. Data performan ayam leher gundul yang dipelihara di Balitnak sudah terkumpul dan ditabulasi. Alternatif konservasi yang dilakukan oleh Balitnak untuk mempertahankan plasma nutfah ayam leher gundul adalah berupa primordial germ cell (PGC) yang dibekukan pada suhu $-196{ }^{\circ} \mathrm{C}$ yang sewaktu-waktu dibutuhkan dapat ditransfer ke embrio resipien. Sumber PGC yang di koleksi adalah dari darah dan gonad embrio. Berdasarkan potensi yang dimilikinya, ayam leher gundul memiliki performan yang baik, sehingga dapat dimanfaatkan sebagai ayam lokal penghasil daging dan telur. Tulisan ini diharapkan dapat bermanfaat sebagai data pendukung bagi upaya pelestarian dan pengembangan ayam-ayam lokal yang ada di Indonesia, khususnya ayam leher gundul dan umumnya ayam-ayam lokal Indonesia lainnya.
\end{abstract}

Kata kunci: ayam leher gundul, performan, konservasi, Balitnak

NAKED NECK CHICKEN: HISTORY, CHARACTERISTIC, AND CONSERVATION

\begin{abstract}
Naked neck chicken is a native/local chicken of Indonesia is not well known in terms of information of the history, potential, and characteristics; so it has not been used optimally. The most striking feature of the naked neck chicken does not have feathers on the neck. To maintain, conservation methods that have been carried out by the Indonesian Research Institute for Animal Production (Balitnak) is to preserve a live animal, but with of limited facilities and infrastructure can not continue. The data of the performance of naked neck chickens of reared in Balitnak have been collected and tabulated. The alternative of conservation undertaken by Balitnak to maintain a naked neck chicken germplasm is in the form of primordial germ cells (PGCs) which are frozen at a temperature of $-196{ }^{\circ} \mathrm{C}$ which when required can be transferred to the recipient embryo. Source PGCs which is collected from the blood and gonad embryonic. Based on its potential, naked neck chicken has good performance, so it can be used as a local chicken producing meat and eggs. This paper is expected to be useful as supporting data for the conservation and development of local chickens in Indonesia, especially naked neck chicken and local chicken of Indonesian of generally.
\end{abstract}

Key words: naked neck chicken, performance, conservation, Balitnak

\section{PENDAHULUAN}

Indonesia merupakan negara mega diversity yaitu negara yang kaya akan keanekaragaman hayatinya, termasuk keanekaragaman ayam-ayam lokal. Sampai saat ini, masih banyak ayam lokal yang belum dimanfaatkan secara optimal padahal ayam lokal memiliki beberapa karakter berharga yang tidak ditemukan pada ayam eksotis. Ayam lokal diketahui mempunyai keanekaragaman sifat genetik yang tinggi seperti warna bulu, kulit, paruh, bentuk jengger, bentuk tubuh, penampilan produksi, pertumbuhan, dan reproduksinya. Salah satu contoh ayam lokal Indonesia yang belum banyak dieksplorasi adalah ayam leher gundul (Gambar 1).

Ayam leher gundul adalah jenis ayam yang secara alami tidak mempunyai bulu dibagian leher, memiliki penampilan tinggi, dan bobot yang berat. Ayam 


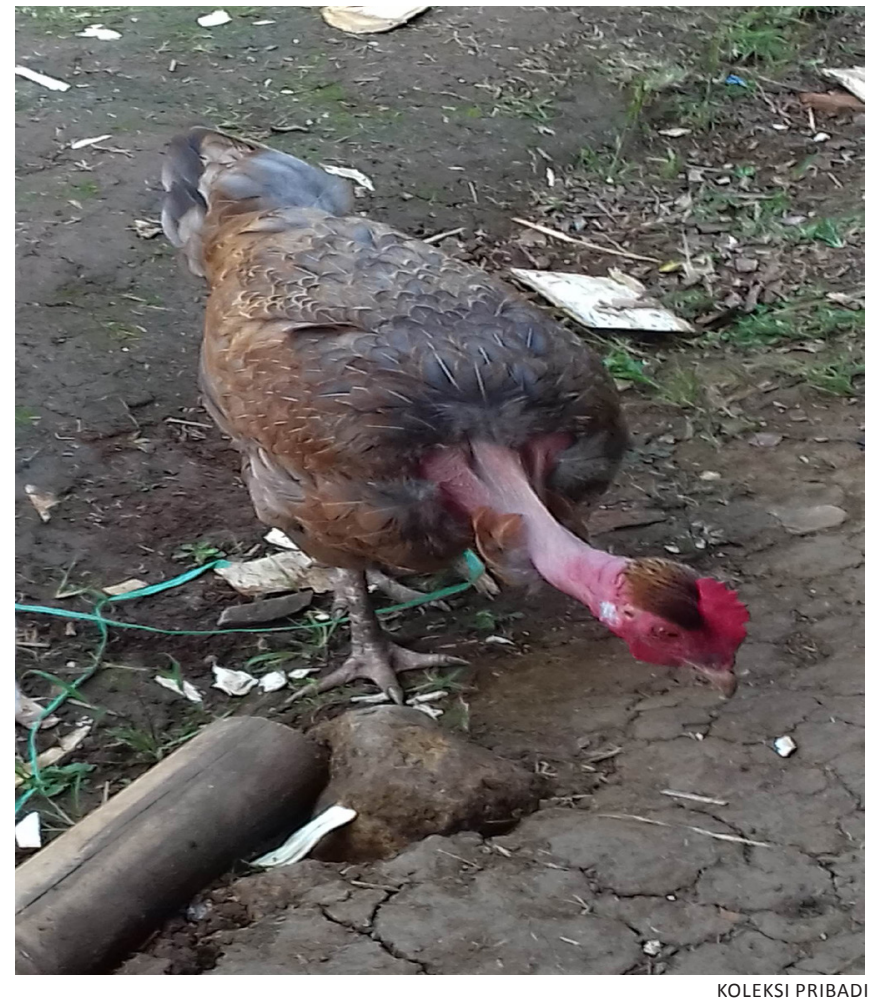

Gambar 1. Ayam leher gundul betina

leher gundul dapat ditemukan di semua negara dan perbedaan di antara ayam-ayam tersebut sangat kecil. Sifat eksterior yang paling terlihat dari ayam leher gundul adalah warna bulu yang berbeda, kualitas daging baik, dan tahan terhadap penyakit (Parker, 2014). Ayam leher gundul pada umumnya dihubungkan dengan Turkens, Transylvania Naked Neck, Bare Necks, Hackleness, dan Rubber Necks, yang seluruhnya memiliki karakteristik sifat leher gundul. Sementara di Indonesia ayam leher gundul dikenal dengan beberapa nama, seperti ayam bali (di Bali) dan ayam ayunai (di Papua) (Sartika et al., 2016).

Ayam lehergundul telah lama dipelihara di Indonesia, sehingga dianggap sebagai ayam lokal. Tingkat keaslian ayam leher gundul yang ada di daerah Subang dan Bogor adalah 35 dan 48 \% (Putri, 2010). Oleh karena itu, tulisan ini diharapkan dapat bermanfaat sebagai data pendukung bagi upaya pelestarian dan pengembangan ayam-ayam lokal yang ada di Indonesia, khususnya ayam leher gundul dan umumnya ayam-ayam lokal Indonesia lainnya.

\section{SEJARAH AYAM LEHER GUNDUL}

Kurangnya informasi yang tepat membuat asal usul ayam leher gundul tidak diketahui secara pasti, sehingga ada 2 pendapat yang menyatakan bahwa asal usul ayam leher gundul yang ada sekarang ini, adalah pertama di duga berasal dari Transylvania, Rumania dan menyebar ke seluruh dunia yang di bawa oleh Dutch East India Company (VOC) dalam rangka perdagangan sekitar abad ke-17 (Ramsey et al., 2000). Kedua menurut ahli sejarah dan spesialis unggas, ayam leher gundul pertama kali di bawa dari Asia menjelang akhir abad ke-19 SM oleh Hun dan telah diketahui selama berabadabad ayam leher gundul dipelihara di selatan Asia Timur (Parker, 2014).

Akan tetapi ada pendapat lain yang menyatakan bahwa penampilan karakteristik genetik ayam-ayam yang ada di Asia Tenggara termasuk di Indonesia, dipengaruhi oleh bangsa-bangsa ayam dari Eropa dan Amerika, yaitu Rhode Island Red, White Leghorn, dan Barred Plymouth Rock (Nishida et al., 1980). Sementara itu, ayam leher gundul yang ada di Subang dan Bogor dipengaruhi oleh bangsa ayam yang berasal dari Barred Plymouth Rock (Putri, 2010).

\section{KARAKTERISTIK FENOTIPE AYAM LEHER GUNDUL}

Sifat fenotipe merupakan penampilan luar atau sifat-sifat lain dari suatu individu yang dapat diamati atau dapat diukur. Sifat fenotipe merupakan ekspresi dari sifat genetik suatu ternak, tampilan warna bulu, kulit, paruh, dan daging, bentuk tubuh, jengger, bulu penutup, penampilan produksi, pertumbuhan dan reproduksi merupakan sifat genetik pada ternak ayam (Sidadolog dan Sasongko, 1990).

Berdasarkan pengamatan Faruque et al. (2010), tanpa membedakan jenis kelamin ayam leher gundul yang ada di Banglades warna bulunya bervariasi ada yang hitam (10\%), coklat kehitaman (60\%), coklat kemerahan (20\%), coklat (5\%) dan macam-macam warna (5\%). Sementara itu, Putri (2010), bahwa warna bulu ayam leher gundul jantan yang ada di Subang dan Bogor 100\% berwarna, sedangkan ayam leher gundul betina di Subang dan Bogor 96 dan 92\% memiliki bulu berwarna dan sisanya 4 dan $8 \%$ adalah warna putih (Tabel 1). Sidadolog (2007) mengatakan bahwa variasi tampilan fenotipe pada ayam lokal dapat terjadi akibat sistem pemeliharaan serta perkawinan yang tidak terkontrol secara baik.

Tampilan warna sisik kaki dan cuping, pada ayam leher gundul betina jauh lebih besar dibandingkan dengan ayam leher gundul jantan. Pada warna sisik kaki ayam leher gundul betina ditemukan 3 warna (putih, hitam, kehijauan) dengan tingkat persentase warna putih jauh lebih besar dibandingkan dengan warna lain. Pada ayam leher gundul jantan, warna sisik kaki ditemukan hanya ada dua warna (putih, hitam), dengan warna putih menjadi warna dominan. Penyebaran warna cuping ayam leher gundul betina lebih besar dibandingkan dengan ayam jantan. Warna cuping 
Tabel 1. Karakteristik kualitatif ayam leher gundul.

\begin{tabular}{|c|c|c|c|c|c|}
\hline \multirow{2}{*}{ Warna } & \multirow{2}{*}{$\begin{array}{c}\text { Bangla- } \\
\text { desh } \\
(\%)^{*}\end{array}$} & \multicolumn{2}{|c|}{ Subang** } & \multicolumn{2}{|c|}{ Bogor** } \\
\hline & & Jantan (\%) & Betina (\%) & Jantan (\%) & ) Betina (\%) \\
\hline \multicolumn{6}{|l|}{ Bulu: } \\
\hline Hitam & 10 & - & - & - & - \\
\hline Putih & - & - & 4 & - & 8 \\
\hline Coklat kehitaman & 60 & - & - & - & - \\
\hline Coklat kemerahan & 20 & - & - & - & - \\
\hline Coklat & 5 & - & - & - & - \\
\hline $\begin{array}{l}\text { Macam-macam } \\
\text { warna }\end{array}$ & 5 & 100 & 96 & 100 & 92 \\
\hline \multicolumn{6}{|l|}{ Corak bulu: } \\
\hline Lurik & - & 100 & 93 & 100 & 83 \\
\hline Polos & - & - & 7 & - & 17 \\
\hline \multicolumn{6}{|l|}{ Kerlip bulu: } \\
\hline Perak & - & 67 & 36 & 38 & 21 \\
\hline Emas & - & 33 & 64 & 62 & 79 \\
\hline \multicolumn{6}{|l|}{ Jengger: } \\
\hline Merah & 40 & - & - & - & - \\
\hline Coklat & 55 & - & - & - & - \\
\hline Pucat & 5 & - & - & - & - \\
\hline \multicolumn{6}{|l|}{ Sisik kaki: } \\
\hline Putih & 30 & 100 & 57 & 62 & 58 \\
\hline Hitam & 15 & - & 43 & 38 & 38 \\
\hline Kuning & 45 & - & - & - & - \\
\hline Kehijauan & 10 & - & - & - & 4 \\
\hline \multicolumn{6}{|l|}{ Cuping: } \\
\hline Merah & - & 100 & 61 & 100 & 79 \\
\hline Putih & 45 & - & - & - & - \\
\hline $\begin{array}{l}\text { Campuran merah } \\
\text { dan putih }\end{array}$ & 35 & - & 39 & - & 8 \\
\hline Kuning & 20 & - & - & - & - \\
\hline Hitam & - & - & - & - & 13 \\
\hline \multicolumn{6}{|l|}{ Mata: } \\
\hline Orange & - & 67 & 64 & 75 & 75 \\
\hline Coklat & - & - & 18 & 25 & 12,5 \\
\hline Pearf & - & 33 & 18 & - & 12,5 \\
\hline \multicolumn{6}{|l|}{ Kerabang telur: } \\
\hline Putih & 56,61 & - & - & - & - \\
\hline Coklat & 9,44 & - & - & - & - \\
\hline Krem & 33,96 & - & - & - & - \\
\hline
\end{tabular}

ayam leher gundul betina ditemukan 3 warna (merah, campuran warna merah dan putih, hitam) dengan persentase warna merah lebih dominan dibandingkan dengan warna yang lain. Pada ayam leher gundul jantan, warna cuping hanya terdiri dari 1 warna, yaitu putih. Ini menunjukkan bahwa variasi warna sisik kaki dan cuping pada betina lebih besar dibandingkan dengan jantan. Variasi pada warna sisik kaki dan cuping kemungkinan besar dipengaruhi oleh genetik (Somes, 1988).

Begitu juga pada warna mata, warna mata ayam leher gusul betina lebih bervariasi dibandingkan dengan ayam leher gundul jantan. Variasi mata ayam leher gundul betina terdiri dari 3 warna (orange, coklat, pearf), sedangkan warna mata ayam leher gundul jantan hanya terdiri dari 2 warna. Dominan warna mata ayan leher gundul betina dan jantan adalah orange.

\section{PERFORMAN AYAM LEHER GUNDUL DI BALAI PENELITIAN TERNAK}

Ayam leher gundul yang dikembangkan di Balai Penelitian Ternak (Balitnak) berasal dari peternak di daerah Kabupaten Bandung dalam bentuk telur tetas. Dari 100 butir telur tetas yang dimasukkan ke dalam mesin inkubator yang berhasil menetas sebanyak 41 ekor unsex. Kematian tertinggi terjadi pada saat embrio umur 18-21 hari dalam inkubator, yaitu sebesar 17,818,7\% (Susanti dan Sopiyana, 2014). Kematian ayam leher gundul masih terjadi, terutama pada ayam umur sehari (DOC) sebanyak 17 ekor, sehingga jumlah ayam leher gundul yang hidup sampai umur 20 minggu sebanyak 24 ekor.

Tingkat produktivitas ternak ditunjukkan dari tingkat kemampuan pertumbuhan serta kinerja reproduksinya. Nilai produktivitas pada ayam diantaranya dapat diukur dari kecepatan bertumbuh dan berkembang yang terlihat dari tingkat kecepatan dalam mencapai suatu bobot badan tertentu dalam umur yang lebih singkat. Sifat pertumbuhan ternak unggas dapat diukur dengan penimbangan bobot badan sejak menetas sampai dewasa kelamin (Tabel 2). Bobot badan ayam leher gundul mengalami kenaikan yang signifikan setiap minggunya, kecuali pada periode starter yaitu umur DOC sampai empat minggu kenaikannya tidak berbeda berkisar antara 7-46 g. Namun setelah umur empat minggu, bobot badan ayam leher gundul mengalami kenaikan. Bobot DOC ayam leher gundul yang dipelihara di Balitnak mencapai 32 g hampir setara dengan DOC ayam sentul $(32,2$ gr) (Susanti et al., 2009), berbeda dengan bobot DOC ayam naked neck yang ada di Bangladesh, yaitu 29,5 g (Faruque et al., 2010). Namun, perbedaan bobot waktu DOC tidak menunjukkan perbedaan ketika mencapai bobot dewasa. Bobot ayam leher gundul pada umur 20 minggu diperoleh sebesar 1,42 kg yang ada di Balitnak, sedangkan bobot badan ayam leher gundul yang ada di Papua Barat bisa mencapai bobot 1,62 kg (Supriyantono et al., 2011).

\section{KARAKTERISTIK PRODUKSI DAN REPRODUKSI AYAM LEHER GUNDUL DI BALAI PENELITIAN TERNAK}

\section{Karakterisitik ukuran tubuh}

Dalam kegiatan pelestarian plasma nutfah, ukuranukuran tubuh atau sifat-sifat kuantitatif merupakan hal yang sangat penting terutama untuk kegiatan 
karakterisasi dan penyusunan database plasma nutfah. Kenyataan menunjukkan bahwa pengukuran ukuran morfologi masih jarang dilakukan. Terbukti dengan masih relatif kurangnya literatur-literatur yang membahas tentang hal ini. Dalam pengelolaan plasma nutfah, kegiatan pengukuran sifat kuantitatif ternak, selain sangat penting dalam upaya karakterisasi ternak, juga sifat kuantitatif mempunyai nilai ekonomis karena mempunyai hubungan yang erat dalam menentukan produksi. Penampilan sifat-sifat kuantitatif ini dipengaruhi oleh genetik dan lingkungan serta interaksi antara genetik dan lingkungan.

Tabel 2. Bobot badan ayam leher gundul yang diamati sejak menetas (DOC) sampai umur 20 minggu yang dipelihara di Balai Penelitian Ternak

\begin{tabular}{cccc}
\hline Umur (minggu) & Bobot badan (g) & KV BB (\%) & PBB (g) \\
\hline 0 & $32 \pm 4$ & 12,7 & \\
1 & $39 \pm 7$ & 18,4 & 7 \\
2 & $57 \pm 11$ & 18,6 & 18 \\
3 & $82 \pm 26$ & 32,3 & 25 \\
4 & $128 \pm 35$ & 27,6 & 46 \\
5 & $183 \pm 38$ & 20,6 & 55 \\
6 & $250 \pm 59$ & 23,7 & 66 \\
7 & $350 \pm 71$ & 20,2 & 100 \\
8 & $433 \pm 85$ & 19,7 & 84 \\
9 & $532 \pm 103$ & 19,4 & 99 \\
10 & $626 \pm 113$ & 18,0 & 94 \\
11 & $726 \pm 141$ & 19,4 & 100 \\
12 & $837 \pm 155$ & 18,5 & 111 \\
13 & $927 \pm 183$ & 19,7 & 91 \\
14 & $1.029 \pm 201$ & 19,6 & 102 \\
15 & $1.124 \pm 226$ & 20,1 & 95 \\
16 & $1.193 \pm 239$ & 20,0 & 69 \\
17 & $1.281 \pm 254$ & 19,8 & 88 \\
18 & $1.326 \pm 251$ & 19,0 & 45 \\
19 & $1.364 \pm 281$ & 20,6 & 38 \\
20 & $1.415 \pm 289$ & 20,4 & 51 \\
\hline
\end{tabular}

Keterangan :

KV: Koefisien variasi; BB: Bobot badan; PBB: Pertambahan bobot badan Sumber : Susanti dan Sopiyana (2014)

Karakteristik ukuran-ukuran tubuh ayam leher gundul (Tabel 3), secara umum bobot serta panjang bagian tubuh ayam leher gundul jantan lebih besar dibandingkan dengan ayam leher gundul betina. Disebabkan ayam jantan memiliki pertumbuhan serta perkembangan tubuh yang jauh lebih cepat dibandingkan dengan ayam betina.

Karakterisitk sifat kuantitatif, ayam leher gundul yang dikoleksi di Balitnak memiliki karakteristik ukuran-ukuran tubuh relatif seragam baik yang jantan maupun betina, karena nilai koefisien variasi/ keragaman bagian-bagian tubuh ayam leher gundul mayoritas bernilai kurang dari $15 \%$, kecuali bagian jengger dan lebar pelvis menunjukkan koefisien variasi yang beragam. Koefisien keragaman yang beragam ini disebabkan oleh keragaman genetik dan keragaman lingkungan. Keragaman lingkungan dapat disebabkan oleh faktor iklim, cuaca, makanan, penyakit, dan sistem manajemen (Noor, 2004).

Hampir sama dengan ayam leher gundul yang ada di Balitnak, ayam leher gundul di Subang dan Bogor, memperlihatkan ukuran-ukuran tubuh seperti panjang shank, panjang tibia, panjang femur, panjang dada, panjang punggung, panjang rentang sayap, lebar dada, lingkar dada, dan lingkar metatarsus menunjukkan koefisien keragaman seragam, dilihat dari nilai keragaman yang kurang dari 20\% (Putri, 2010).

\section{Kualitas telur}

Tampilan kualitas telur ayam leher gundul disajikan pada Tabel 4. Udoh et al. (2012) melaporkan bahwa bobot telur ayam leher gundul yang ada di Nigeria dapat mencapai bobot telur 45,82 gr.

Dengan bobot telur yang lebih ringan, ternyata tebal kerabang untuk telur ayam leher gundul di Balitnak lebih tebal dibandingkan dengan tebal kerabang telur ayam leher gundul yang ada di Nigeria $(0,37 \mathrm{~mm}$; Udoh et al., 2012). Berarti telur ayam leher gundul yang ada di Balitnak tidak mudah mengalami kerusakan (pecah), karena Chineke (2001) melaporkan bahwa kerabang telur yang tipis akan menyebabkan telur mudah mengalami resiko kerusakan dan mudah dimasuki oleh mikro organisme.

Rataan persentase HU telur ayam leher gundul di Balitnak sangat jauh dibandingkan dengan HU telur ayam leher gundul di Nigeria yang dapat mencapai 82,49\% (Rajaravindra et al., 2015). Skor warna kuning telur ayam leher gundul sangat bervariasi, mulai dari skor 3 sampai skor 10. Inkonsistensi dalam warna kuning telur mungkin karena deposisi pigmen karotenoid yang bervariasi.

\section{Kualitas karkas}

Kualitas karkas ayam leher gundul di Balitnak lebih baik daripada ayam naked neck umur 16 minggu yang diberi pakan ad lib menghasilkan bobot karkas sebesar 1050,1 g/ekor (Tabel 5) (Chikumba dan Chimonyo, 2014). Pada jantan, bobot komponen karkas tertinggi pada bagian punggung (20,24\%), kemudian bagian dada (19,85\%), bagian paha atas (17,85\%), paha bawah (14,94\%), dan terakhir bagian sayap (10,41\%); sedangkan pada betina, bobot komponen karkas tertinggi pada bagian dada (23,66\%), kemudian bagian punggung (23,48\%), bagian paha atas $(16,17 \%)$, bagian paha bawah $(12,75 \%)$, dan terakhir bagian sayap (10,54\%) (Kostaman dan Sopiyana, 2015a). Sama dengan yang dilaporkan Gunawan dan Sartika (2001) untuk ayam pelung jantan yang dikawinkan dengan 
Tabel 3. Karakteristik ukuran-ukuran bagian tubuh ayam leher gundul dewasa

\begin{tabular}{|c|c|c|c|c|c|c|c|c|}
\hline \multirow{3}{*}{ Bagian tubuh } & \multicolumn{4}{|c|}{ Balitnak } & \multicolumn{2}{|c|}{ Subang } & \multicolumn{2}{|c|}{ Bogor } \\
\hline & \multicolumn{2}{|c|}{ Betina $^{1}$} & \multicolumn{2}{|c|}{$\operatorname{Jantan}^{1}$} & \multirow{2}{*}{$\begin{array}{c}\text { Betina }^{2} \\
\text { Rataan } \pm \text { SD }\end{array}$} & \multirow{2}{*}{$\begin{array}{c}\text { Jantan }^{2} \\
\text { Rataan } \pm \text { SD }\end{array}$} & \multirow{2}{*}{$\begin{array}{c}\text { Betina }^{2} \\
\text { Rataan } \pm S D\end{array}$} & \multirow{2}{*}{$\begin{array}{c}\text { Jantan }^{2} \\
\text { Rataan } \pm S D\end{array}$} \\
\hline & Rataan $\pm S D$ & $\begin{array}{c}\text { Koefisien } \\
\text { variasi (\%) }\end{array}$ & Rataan $\pm S D$ & $\begin{array}{c}\text { Koefisien } \\
\text { variasi (\%) }\end{array}$ & & & & \\
\hline Panjang badan $(\mathrm{cm})$ & $36,8 \pm 1,1$ & 3,0 & $43,0 \pm 2,8$ & 6,5 & - & - & - & - \\
\hline Tinggi badan $(\mathrm{cm})$ & $27,5 \pm 2,1$ & 7,6 & $29,3 \pm 1,1$ & 2,8 & - & - & - & - \\
\hline Panjang dada (cm) & $16,8 \pm 0,4$ & 2,4 & $20,0 \pm 0,5$ & 2,5 & $9,30 \pm 1,24$ & $9,50 \pm 1,24$ & $9,20 \pm 1,34$ & $9,60 \pm 0,84$ \\
\hline Lebar dada $(\mathrm{cm})$ & $10,8 \pm 0,4$ & 3,7 & $11,3 \pm 0,4$ & 3,5 & $16,50 \pm 1,90$ & $18,10 \pm 3,10$ & $10,00 \pm 1,74$ & $11,80 \pm 1.63$ \\
\hline Lingkar dada $(\mathrm{cm})$ & $29,5 \pm 2,1$ & 7,1 & $33,0 \pm 1,4$ & 4,2 & $25,20 \pm 2,70$ & $25,60 \pm 3,37$ & $27,80 \pm 3,88$ & $29,30 \pm 5,74$ \\
\hline Panjang punggung $(\mathrm{cm})$ & $18,8 \pm 0,4$ & 2,1 & $22,3 \pm 1,1$ & 4,9 & $13,70 \pm 1,93$ & $14,70 \pm 1,14$ & $12,50 \pm 1,89$ & $12,60 \pm 1,08$ \\
\hline Panjang sayap (cm) & $18,5 \pm 0,7$ & 3,8 & $22,0 \pm 1,4$ & 6,4 & $18,70 \pm 1,61$ & $8,90 \pm 0,87$ & $18,20 \pm 1,79$ & $20,80 \pm 1,72$ \\
\hline Panjang leher $(\mathrm{cm})$ & $11,8 \pm 0,4$ & 3,4 & $14,0 \pm 1,4$ & 10,0 & - & - & - & - \\
\hline Panjang paruh (mm) & $30,9 \pm 0,8$ & 1,3 & $33,9 \pm 0,9$ & 2,7 & - & - & - & - \\
\hline Lebar paruh $(\mathrm{mm})$ & $21,3 \pm 0,4$ & 1,9 & $22,5 \pm 1,9$ & 8,4 & - & - & - & - \\
\hline Tebal paruh $(\mathrm{mm})$ & $11,0 \pm 0,1$ & 0,9 & $11,4 \pm 0,5$ & 4,4 & - & - & - & - \\
\hline Lebar kepala (mm) & $31,2 \pm 2,2$ & 7,1 & $35,9 \pm 0,3$ & 0,8 & - & - & - & - \\
\hline Panjang kepala (mm) & $46,8 \pm 0,6$ & 1,3 & $47,7 \pm 3,6$ & 7,5 & - & - & - & - \\
\hline Panjang femur $(\mathrm{cm})$ & $9,0 \pm 1,4$ & 15,6 & $10,5 \pm 0,7$ & 6,7 & $9,00 \pm 0,94$ & $10,60 \pm 1,22$ & $8,80 \pm 0,88$ & $9,70 \pm 1,62$ \\
\hline Panjang tibia $(\mathrm{cm})$ & $10,5 \pm 0,7$ & 6,7 & $14,8 \pm 1,1$ & 7,4 & $10,90 \pm 1,26$ & $8,30 \pm 0,34$ & $12,10 \pm 1,17$ & $13,40 \pm 1,21$ \\
\hline Panjang shank $(\mathrm{cm})$ & $6,8 \pm 0,4$ & 5,9 & $9,5 \pm 1,4$ & 14,7 & $8,60 \pm 0,96$ & $8,30 \pm 0,34$ & $7,70 \pm 0,867$ & $8,60 \pm 0,74$ \\
\hline Lingkar shank $(\mathrm{cm})$ & $3,5 \pm 0,2$ & 5,7 & $4,8 \pm 0,4$ & 8,3 & - & - & - & - \\
\hline Lebar pelvis $(\mathrm{mm})$ & $39,7 \pm 6,8$ & 17,1 & $25,2 \pm 7,7$ & 30,6 & - & - & - & - \\
\hline Tinggi jengger $(\mathrm{mm})$ & $13,0 \pm 3,2$ & 24,6 & $33,1 \pm 6,7$ & 20,2 & - & - & - & - \\
\hline Panjang jengger (mm) & $23,0 \pm 4,5$ & 19,6 & $50,1 \pm 14,0$ & 27,9 & - & - & - & - \\
\hline Tebal jengger (mm) & $6,5 \pm 0,6$ & 9,2 & $13,7 \pm 1,4$ & 10,2 & - & - & - & - \\
\hline
\end{tabular}

Keterangan: SD=standar deviasi. ${ }^{1}$ Susanti dan Sopiyana (2014), ${ }^{2}$ Putri (2010)

Tabel 4. Beberapa karakteristik kualitas telur ayam leher gundul yang dipelihara di Balai Penelitian Ternak

\begin{tabular}{cc}
\hline \multicolumn{1}{c}{ Peubah } & Nilai \\
\hline Bobot telur (gram) & $37,66 \pm 7,37$ \\
Tebal kerabang (mm) & $0,43 \pm 0,04$ \\
Haugh Unit (HU) (\%): & $57,62 \pm 11,69$ \\
AA & 8,16 ( 4 telur) \\
A & 32,66 (16 telur) \\
B & 59,18 (29 telur) \\
Skor warna kuning telur (\%): & \\
3 & 2,04 ( 1 telur) \\
4 & 22,46 (11 telur) \\
5 & 48,98 (24 telur) \\
7 & 12,24 ( 6 telur) \\
8 & 6,12 ( 3 telur) \\
9 & 6,12 ( 3 telur) \\
10 & 2,04 ( 1 telur) \\
\hline
\end{tabular}

Keterangan: Bentuk tabel dimodifikasi

Sumber: Kostaman dan Sopiyana (2016)

ayam kampung betina, urutan komponen karkas dari yang tertinggi sampai dengan yang terendah adalah bagian punggung, kemudian diikuti bagian dada, paha atas, paha bawah, dan sayap.

Rataan bobot organ bagian dalam (hati, ampela, usus, dan jantung; Tabel 6) ayam leher gundul di Balitnak lebih rendah dengan yang dilaporkan Chikumba dan Chimonyo (2014) yaitu rataan bobot hati sebesar 34,4
Tabel 5. Bobot hidup dan potongan komersial (dada, paha, sayap dan punggung) ayam leher gundul

\begin{tabular}{lcc}
\hline \multirow{2}{*}{ Peubah } & \multicolumn{2}{c}{ Jenis Kelamin Ayam } \\
\cline { 2 - 3 } & Betina (20) & Jantan (17) \\
\hline Bobot hidup (gram) & $1556,00 \pm 244,35$ & $2244,88 \pm 322,83$ \\
Karkas (gram) & $1197,35 \pm 200,29$ & $1886,00 \pm 285,96$ \\
Dada (gram) & $283,25 \pm 65,43$ & $374,29 \pm 66,23$ \\
Paha atas (gram) & $193,65 \pm 32,33$ & $336,59 \pm 70,50$ \\
Paha bawah (gram) & $152,65 \pm 31,35$ & $281,71 \pm 43,70$ \\
Sayap (gram) & $126,25 \pm 20,80$ & $196,29 \pm 27,94$ \\
Punggung (gram) & $281,15 \pm 53,17$ & $381,65 \pm 70,91$ \\
\hline
\end{tabular}

Sumber: Kostaman dan Sopiyana (2015a)

g, tetapi lebih tinggi dari Isidahomen et al. (2012) yang mendapatkan rataan bobot hati sebesar 24,5 g. Rataan bobot jantung lebih tinggi dengan yang dilaporkan oleh Chikumba dan Chimonyo (2014) dan Isidahomen et al. (2012).

Tabel 6. Bobot organ bagian dalam dari ayam leher gundul

\begin{tabular}{lcc}
\hline \multirow{2}{*}{ Peubah } & \multicolumn{2}{c}{ Jenis Kelamin Ayam } \\
\cline { 2 - 3 } & Betina (20) & Jantan (17) \\
\hline Hati (gram) & $33,30 \pm 7,71$ & $29,12 \pm 5,45$ \\
Ampela (gram) & $34,70 \pm 9,11$ & $43,41 \pm 8,14$ \\
Usus (gram) & $82,60 \pm 24,41$ & $78,82 \pm 14,75$ \\
Jantung (gram) & $8,65 \pm 2,37$ & $13,06 \pm 2,54$ \\
\hline
\end{tabular}

Sumber: Kostaman dan Sopiyana (2015a) 
Rataan bobot non karkas (kepala, leher, dan ceker; Tabel 7), dimana rataan bobot kepala lebih tinggi dengan yang dilaporkan Isidahomen et al. (2012), yaitu bobot kepala jantan dan betina adalah 50,4 dan 46,2 g. Untuk rataan bobot leher, rataan bobot leher jantan lebih tinggi, yaitu 120,24 vs 81,2 g (Isidahomen et al., 2012), sedangkan rataan bobot leher betina lebih rendah, yaitu 56,15 vs 72,2 g (Isidahomen et al., 2012).

Tabel 7. Bobot non karkas (kepala, leher dan ceker) dari ayam leher gundul

\begin{tabular}{lcc}
\hline \multirow{2}{*}{ Peubah } & \multicolumn{2}{c}{ Jenis Kelamin Ayam } \\
\cline { 2 - 3 } & \multicolumn{1}{c}{ Betina (20) } & Jantan (17) \\
\hline Kepala (gram) & $51,00 \pm 9,31$ & $97,29 \pm 26,74$ \\
Leher (gram) & $56,15 \pm 11,56$ & $120,24 \pm 22,96$ \\
Dua ceker (gram) & $53,25 \pm 14,63$ & $97,94 \pm 16,99$ \\
\hline
\end{tabular}

Sumber: Kostaman dan Sopiyana (2015a)

\section{Kualitas semen}

Kualitas semen segar dari koleksi ayam leher gundul memperlihatkaan rataan volume semen 0,44 $\mathrm{ml}$ (Tabel 8) masih ada dalam kisaran volume semen normal yang biasa dihasilkan oleh ayam, yaitu 0,34-0,59 ml pada ayam broiler dan 0,40-0,73 ml pada tujuh ayam lokal yang berbeda (Bilcik et al., 2005; Peters et al. 2008). Rataan volume semen ayam leher gundul sedikit lebih tinggi daripada ayam pelung (Asmarawati et al.. 2013), ayam arab dan ayam bangkok (Irastuti, 2011).

Tabel 8. Rataan karakteristik kualitas semen segar ayam leher gundul yang dipelihara di Balai Peneitian Ternak

\begin{tabular}{lc}
\hline \multicolumn{1}{c}{ Peubah } & Rataan \pm Standar Deviasi \\
\hline Volume $(\mathrm{ml})$ & $0,44 \pm 0,05$ \\
Motilitas $(\%)$ & $77,20 \pm 2,17$ \\
Konsentrasi $\left(\times 10^{9} / \mathrm{ml}\right)$ & $1,86 \pm 0,23$ \\
Konsistensi & Kental \\
Warna & Putih krem \\
\hline
\end{tabular}

Sumber: Kostaman dan Sopiyana (2015b)

Motilitas sperma menjadi penting pada saat pembuahan karena memungkinkan atau setidaknya memfasilitasi lewatnya sperma melalui zona pelusida (Debby et al., 2012). Nilai persentase motilitas sperma koleksi ayam leher gundul berada dalam kisaran 7087,35\% (Peters et al. 2008) serta pada kisaran 74,5$85,67 \%$ (Tabatabaei et al. 2010) pada ayam broiler di Iran. Nilai konsentrasi ayam leher gundul lebih rendah dengan yang dilaporkan Tabartabaei et al. (2010), yaitu 2,17-3,14 X10 $9 / \mathrm{ml}$.

Warna semen segar ayam leher gundul adalah putih krem dengan konsistensi kental dan tidak berbeda dengan ayam buras, ayam arab dan ayam bangkok (Irastuti, 2011). Sementara itu, warna semen ayam pelung berwarna putih (Asmarawati et al., 2013).

\section{KONSERVASI AYAM LEHER GUNDUL DI BALAI PENELITIAN TERNAK}

Konservasi yang sudah umum dilakukan di banyak negara adalah dengan cara in situ dan ex situ. Konservasi in situ bersifat pasif, dapat terlaksana hanya dengan mengamankan tempat tumbuh alamiah suatu jenis. Dimana jenis-jenis tertentu diberi kesempatan berkembang dan bertahan dalam keadaan lingkungan alam dan habitat yang asli, serta tidak ada campur tangan manusia. Sementara itu, konservasi secara ex situ bersifat aktif, yaitu dengan cara memindahkan sesuatu jenis ke suatu lingkungan atau tempat pemeliharaan baru di luar habitat alamiahnya dan ada campur tangan manusia.

Balai Penelitian Ternak, sampai dengan awal tahun 2015 mengkoleksi ayam leher gundul sebagai hewan hidup. Akan tetapi dengan keterbatasan sarana dan prasarana kandang pada akhir tahun 2015 koleksi hidup dari ayam leher gundul harus dikeluarkan dari Balitnak.

Untuk mempertahankan sumber daya genetik dari ayam leher gundul, koleksi yang tersimpan sekarang adalah dalam bentuk primordial germ cell (PGC) yang di simpan dalam nitrogen cair (suhu $-196^{\circ} \mathrm{C}$ ). Pembekuan PGC ini sewaktu-waktu dibutuhkan dapat di transfer ke embrio resipien. Secara rinci tulisan tentang isolasi, konservasi, dan transfer dari PGC sudah dilaporkan Setioko (2008), Sopiyana et al. (2008), Setioko et al. (2010), Kostaman et al. (2011, 2012, 2013, 2014), Kostaman (2014a, b), Kostaman dan Sopiyana (2014a, b, 2015c, 2016), dan Sopiyana et al. (2016). Primordial germ cell yang di koleksi dari darah atau gonad embrio dapat dibekukan dan digunakan untuk menghasilkan germline chimera, serta memungkinkan pelestarian baik plasma nutfah jantan dan betina (Petitte, 2006).

\section{SIMPULAN}

Berdasarkan potensi yang dimilikinya, ayam leher gundul memiliki performans yang baik. Oleh karena itu, ayam leher gundul sangat baik bila dimanfaatkan sebagai ayam lokal penghasil daging dan telur. Populasi ayam leher gundul yang tinggal sedikit, menuntut upaya pengembangan lebih lanjut, disamping itu juga untuk melestarikan plasma nutfah asli Indonesia. Upaya pelestarian yang dikembangakan Balitnak adalah dengan teknologi pembekuan PGC yang sewaktu-waktu dibutuhkan dapat di transfer ke embrio resipien.

\section{UCAPAN TERIMAKASIH}

Penulis mengucapkan terima kasih kepada Kepala Balai yang telah memfasilitasi pendanaan melalui DIPA APBN BALITNAK dan seluruh tim yang membantu kelancaran penelitian. 


\section{DAFTARPUSTAKA}

Asmarawati, W., Kustono, D. T. Widayati, S. Bintara, dan Ismaya. 2013. Pengaruh dosis sperma yang diencerkan dengan $\mathrm{NaCl}$ fisiologis terhadap fertilitas telur pada inseminasi buatan ayam lokal. Buletin Peternakan. 37:1-5.

Bilcik, B., I. Estevez, dan E. Russek-Cohen. 2005. Reproductive success of broiler breeders in natural mating systems: The effect of male-male competition, sperm quality and, morphological characteristics. Poult. Sci. 84:1453-1462.

Chikumba, N. dan M. Chimonyo. 2014. Effects of water restriction on the growth performance, carcass characteristics and organ weights on Naked Neck and Ovambo chickens of Southern Africa. AJAS. 27:974-980.

Chineke, C. A. 2001. Inter-relationships existing between body weight and egg production traits in Olympic black layers. Nigeria J. Anim. Prod. 28:1-8.

Debby, I., F. Maya, dan B. Haim. 2012. Mechanism of sperm capacitation and the acrosome reaction: role of protein kinases. Asian J. Andro. Adv.10:1038.

Faruque, S., N. U. Siddiquee, M. A. Afroz, dan M. S. Islam. 2010. Phenotypic characterization of native chicken reared under intensive management system. J. Bangladesh Agril. Univ. 8:79-82.

Gunawan, B. dan T. Sartika. 2001. Persilangan ayam Pelung jantan X Kampung betina hasil seleksi generasi kedua (G2). JITV. 6:21-27.

Irastuti. 2011. Pengaruh bangsa pejantan dan interval deposisi semen terhadap keberhasilan inseminasi buatan pada ayam. Jurnal Sains dan Teknologi Tadulako. 1:13-25.

Isidahomen, C. E., B. M. Ilori, dan K. Akano. 2012. Genetic and sex differences in carcass traits of Nigerian indigenous chickens. J. Anim. Sci. Adv. 2:637-648.

Kostaman, T. 2014a. Metode purifikasi dan penyimpanan primordial germ cells-sirkulasi untuk pelestarian ayam lokal. Wartazoa. 24:161-170.

Kostaman, T. 2014b. Primordial germ cell: proses dan aplikasinya. Di dalam: Peran Bioteknologi dalam Peningkatan Populasi dan Mutu Genetik Ternak Mendukung Kemandirian Daging dan Susu Nasional. Prosiding Seminar Nasional dan Forum Komunikasi Industri Peternakan, 24 September 2014. LIPI, Bogor. Halaman 302-316.

Kostaman, T. dan S. Sopiyana. 2014a. Pengaruh spesies ayam terhadap kualitas internal telur dan jumlah primordial germ cell sirkulasi ayam lokal Indonesia. Di dalam: Pengembangan Peternakan Berbasis Sumberdaya Lokal Menuju Kedaulatan Pangan. Prosiding Seminar Nasional Peternakan Berkelanjutan 6, 18 November 2014. Fakultas Peternakan
UNPAD, Jatinangor. Halaman 411-418.

Kostaman, T. dan S. Sopiyana. 2014b. Efektivitas pembekuan terhadap recovery rate dan viabilitas primordial germ cell ayam lokal Indonesia. Di dalam: Teknologi Peternakan dan Veteriner Mendukung Pertanian Bioindustri Berkelanjutan. Prosiding Seminar Nasional Teknologi Peternakan dan Veteriner, 12-14 September 2014. Puslitbang Peternakan, Malang. Halaman 554-559.

Kostaman, T. dan S. Sopiyana. 2015a. Karakteristik karkas ayam leher gundul. Di dalam: Teknologi Peternakan dan Veteriner untuk Peningkatan Daya Saing dan Mewujudkan Kedaulatan Pangan. Prosiding Seminar Nasional Teknologi Peternakan dan Veteriner, 8-9 Oktober 2015. Puslitbang Peternakan, Jakarta. Halaman 448-452.

Kostaman, T. dan S. Sopiyana. 2015b. Karakteristik kualitas semen ayam Leher Gundul yang dipelihara di Balai Penelitian Ternak. Prosiding Seminar Nasional Pengembangan Sumber Daya Genetik Pertanian, Bogor. Halaman 540-543.

Kostaman, T. dan S. Sopiyana. 2015c. Isolasi gonadal germ cell (GGC) dari perkembangan awal embrio ayam kampung unggul Badan Litbang Pertanian (KUB). Di dalam: Pengembangan Sumber Daya Lokal dalam Agribisnis Peternakan. Prosiding Seminar Nasional Peternakan Berkelanjutan 7, 11 November 2015. Fakultas Peternakan UNPAD, Jatinangor. Halaman 44-48.

Kostaman, T. dan S. Sopiyana. 2016. The differences in egg quality of white leghorn and naked neck chicken. In: Promoting Livestock and Veterinary Technology for Sustainable Rural Livestock Development. International Seminar on Livestoc Production and Veterinary Technology, August $10^{\text {th }}-12^{\text {th }} 2016$. Puslitbang Peternakan, Bali. pp. 365-369.

Kostaman, T., S. Sopiyana, dan A. R. Setioko. 2011. Tingkat penurunan suhu pada kriopreservasi primordial germ cell (PGC) dari tiga jenis ayam lokal Indonesia. JITV. 16:218-223.

Kostaman, T., S. Sopiyana, dan A. R. Setioko. 2012. Teknik pengembangan primordial germ cell ayam lokal. Di dalam: Pengembangan Peran Unggas Lokal dalam Iindustri Perunggasan Nasional. Prosiding Workshop National Unggas Lokal, Oktober 2012. Puslitbang Peternakan, Jakarta. Halaman 84-92.

Kostaman, T., T. L. Yusuf, M. Fahrudin, dan M. A. Setiadi. 2013. Isolasi dan jumlah primordial germ cell sirkulasi (PGC-Sirkulasi) pada stadium perkembangan embrio ayam gaok. JITV. 18:27-33.

Kostaman, T., T. L. Yusuf, M. Fahrudin, M. A. Setiadi, dan A. R. Setioko. 2014. Pembentukan germline chimera ayam gaok menggunakan primordial germ cell sirkulasi segar dan beku. JITV. 19:17-25. 
Nishida, T., K. Nozawa, K. Kondo, S. S. Mansjoer, and H. Martojo. 1980. Morphological and genetical studies in the Indonesian native fowl. The Origin Phylogeny Indonesian Native Livestock I:47-70.

Noor, R. R. 2004. Genetika Ternak. Penebar Swadaya, Jakarta.

Parker, R. 2014. Concerning poultry: The positive traits of naked neck chickens. Aviculture Europe. 10:6.

Peters, S. O, O. D. Shoyebo, B. M. llori, M. O. Ozoje, C. O. N. Ikeobi, and O. A. Adebambo. 2008. Semen quality traits of seven strain of chickens raised in the humid tropics. Int. J. Poult. Sci. 7:949-953.

Petitte, J. N. 2006. Avian germplasm preservation: embryonic stem cells or primordial germ cells? Poult. Sci. 85:237-242.

Putri, D. A. 2010. Karakteristik Kualitatif dan Kuantitatif Ayam Leher Gundul (Legun) di Kabupaten Subang dan Bogor, Jawa Barat Skripsi. Institut Pertanian Bogor, Bogor.

Rajaravindra, K. S., U. Rajkumar, K. Rekha, M. Niranjan, B. L. N. Reddy, dan R. N. Chatterjee. 2015. Evaluation of egg quality traits in a synthetic coloured broiler female line. J. App. Anim. Res. 43:10-14, http://dx.doi.org/10.1080/ 09712119.2014.883319.

Ramsey, K., L. Harris, dan A. Kotze. 2000. Landrace breeds: South Africa'S indigenous and locally adapted developed farm animals. INFPD newsletter. 2:18-20.

Sartika, I., S. Iskandar, dan B. Tiesnamurti. 2016. Mengenal Plasma Nuftah Ayam Indonesia dan Pemanfaatannya. Puslitbangnak, Bogor.

Setioko, A. R. 2008. Konservasi plasmanutfah unggas melalui kriopreservasi primordial germ cells (PGCs). Wartazoa. 18:68-77.

Setioko, A. R., T. Kostaman, dan S. Sopiyana. 2010. Jumlah primordial germ cells (PGC) pada beberapa tingkat umur embrio yang berbeda pada ayam buras dan ras. Di dalam: Peran IPTEK Bidang Biologi dalam Melestarikan Kearifan Masyarakat untuk Mendukung Pemanfaatan Sumber Daya Alam yang Berkelanjutan. Prosiding Seminar Nasional Biologi, 6 Desember 2010. Jurusan Biologi Fakultas Matematika dan Ilmu Pengetahun Alam UNPAD, Jatinangor.

Sidadolog, J. H. P. 2007. Pemanfaatan dan kegunaan ayam lokal Indonesia (Utilisation of local chickens in Indonesia)', in K Diwyanto \& SN Prijono (eds), Keanekaragaman sumber daya hati ayam lokal In- donesia: manfaat dan potensi, LIPI Press, Jakarta, Indonesia.

Sidadolog, J. H. P. dan H. Sasongko. 1990. Genetika Produksi Telur dan Pertumbuhan pada Ayam Lokal. Laporan Penelitian No. 232/P4M/DPPM/BDXXI/ 1989. Fakultas Peternakan Universitas Gadjah Mada, Yogyakarta.

Somes, R. G. 1988. International registry of poultry genetic stocks. Storrs Agric. Expt Sta. (Univ. Connecticut) Docum. No. 476. pp. 98.

Sopiyana, S., I. Supriatna, M. A. Setiadi, and M. Fahrudin. 2016. Determination of production capacity of circulated primordial germ cell (Circulated-PGC) of KUB chicken using lysis buffer ammonium chloride potassium (ACK). JITV. 21:55-61.

Sopiyana, S., T. Kostaman, dan A. R. Setioko. 2008. Pemurnian primordial germ cells (PGCs) ayam lokal dengan metode nicodenz density gradient centrifugation (NGC). Di dalam: Inovasi Teknologi Mendukung Pengembangan Agribisnis Peternakan Ramah Lingkungan. Prosiding Seminar Nasional Teknologi Peternakan dan Veteriner, 11-12 November 2008. Puslitbang Peternakan, Bogor. Halaman 576-581.

Supriyantono, A., KA. I. Illian, dan M. J. Wajo. 2011. Potensi ayam leher gundul sebagai sumber daging ayam buras. Di dalam: Teknologi Peternakan dan Veteriner untuk Peningkatan Produksi dan Antisipatif terhadap Dampak Perubahan Iklim. Prosiding Seminar Nasional Teknologi Peternakan dan Veteriner, 7-8 Juni 2011. Puslitbang Peternakan, Bogor. Halaman 685-690.

Susanti, T. dan S. Sopiyana. 2014. Karakteristik pertumbuhan dan ukuran tubuh dewasa ayam leher gundul sebagai sumber daya genetik ayam lokal di Indonesia. Di dalam: Teknologi Peternakan dan Veteriner Mendukung Pertanian Bioindustri Berkelanjutan. Prosiding Seminar Nasional Peternakan dan Veteriner, 12-14 September 2014. Puslitbang Peternakan, Malang. Halaman 532-537.

Tabatabaei, S., M. Chaji, and T. Mohammadabadi. 2010. Correlation between age of rooster and semen quality in Iranian indigenous broiler breeder chickens. J. Anim. Vet. Adv. 9:195-198.

Udoh, U. H, B. Okon, and A. P. Udoh. 2012. Egg quality characteristics, phenotypic correlations and prediction of egg weight in three (Naked Neck, Frizzled Feather and Normal Feathered) Nigerian local chickens. Int. J. Poult. Sci. 11:696-699. 